\title{
TRACKING FIVE YEARS OF TEACHER EDUCATION ENROLMENT AT A SOUTH AFRICAN UNIVERSITY: IMPLICATIONS FOR TEACHER EDUCATION
}

\author{
N. Davids* \\ e-mail: nur@sun.ac.za / https://orcid.org/0000-0002-7588-5814
}

\section{Y. Waghid* \\ e-mail: yw@sun.ac.za / https://orcid.org/0000-0003-2565-824X}

*Department of Education Policy Studies

Stellenbosch University

Stellenbosch, South Africa

\section{ABSTRACT}

The faculty in which we are based offers two initial teacher training programmes: the Postgraduate Certificate in Education (PGCE); and the four-year BEd qualification - allowing students to pursue a specialisation in either the foundation or intermediate phase. Compared to other faculties, the Faculty of Education occupies the somewhat precarious label of being one of the "most transformed" faculty in the university. In other words, given the historical privilege of the university, the Faculty of Education is considered to have shown the most evident strides towards transformation in terms of racial representation. A cursory glance at statistics of student enrolments over a five-year period, provides interesting insights - insights, which, as we shall discuss in this article, should be interpreted with great caution. The interest and purpose of this article is to use the student enrolment statistics at a historically advantaged university as one indicator of a representative sample of teachers, who are likely to enter South African schools. The interest, on the one hand, is to gain an idea of the corpus of enrolled student teachers - by taking account of race and gender. On the other hand, we intend to use this data to further our discussions on representation, and the implications for teacher education, and hence, teaching. In the background, are inevitable concerns centring on notions of representation in relation to conceptions of transformation.

Keywords: Teacher education; representation; race; gender; transformation

\section{INITIAL TEACHER EDUCATION PROGRAMMES - A BACKGROUND GLANCE}

South Africa's dual afflictions of first colonialism by the Dutch, followed by the British - a pattern which repeated itself - and then apartheid in 1948, have played significant and dire roles 
in relation to people's identities, and sense of humanity. In both cases of colonialism and apartheid, education was weaponised to advance distorted and damaging agenda of segregated and hegemonic discourses. Apartheid concretised racial categories - creating not only 19 different education departments, based on race and ethnicity, but limited "coloured", "black", and "Indian" communities in terms of tertiary education options, and hence, career choices. One of the career pathways that the apartheid government advocated for "non-whites" was teaching, made possible by the provision of a state bursary.

Teacher education institutions in South Africa, explains Chisholm (2009, 14), developed in a haphazard way out of mission schools, universities and a host of local and regional initiatives, but from the 1960s onwards were more forcefully planned and segregated along the lines of race and ethnicity. Generally, say Chisholm (2009), students intending to become primary school teachers trained at provincially-controlled racially segregated colleges of education, and would-be secondary school teachers trained at segregated universities. Colleges of education proliferated from the 1960s, when the apartheid state used them to control and divert African aspirations and advancement from urban areas by locating higher education institutions in the "homelands" (economically unviable areas) - where it was hoped the graduates would eventually become based (Chisholm 2009). According to Chisholm (2009, 14), high enrolments in education colleges during the apartheid period resulted partly because positions in the formal economy were limited and partly because they provided the possibility for some form of higher education. Moreover, information about the number of institutions providing training, the number of students in training, and the number of students qualifying when the college system was in existence, is poor.

The future of education colleges formed part of the massive educational reform which accompanied South Africa's transition from apartheid to democracy during the early and mid1990s. There were two prominent views regarding the education colleges. One proposal by the National Commission on Higher Education (NCHE), was that the colleges be incorporated into universities. The opposing proposal, submitted by the College Council of Education Rectors, was that the colleges should retain a degree of autonomy (Chisholm 2009). In the end, says Chisholm $(2009,16)$, budgetary concerns dictated the outcome, and colleges of education were given the option to become autonomous higher education institutions if they could achieve a minimum enrolment of 2000 full-time-equivalent students, or to become part of existing universities and universities of technology. From 1997 onwards, provinces controlled the supply of teachers by placing stringent quotas on new enrolments, leading to a rapid decline in college enrolments - from 71000 (or 80 000) in 1994 to 15000 in 2000 (Chisholm 2009).

At the same time, teacher education curriculum changes were placing further stresses on 
institutions. The Norms and Standards for Educators (DoE 2000) introduced a national core curriculum based on seven roles of teachers and linked teacher education to the National Qualifications Framework (NQF) - identified as learning mediator; interpreter and designer of learning programmes and materials; leader, administrator and manager; scholar, researcher and lifelong learner; community, citizenship and pastoral role; assessor; learning area/subject/ discipline/phase specialist. Seven years later, the Department of Higher Education and Training (DHET) introduced the Minimum Requirements for Teacher Education Qualifications (DHET 2015). The shift towards learner-centred learning brought about by a post-apartheid outcomesbased curriculum, has had particular implications for teaching and teachers in South Africa. The Minimum Requirements for Teacher Education Qualifications selected from the HEQF (DHET 2015, 9) recognises the importance of both integrated and applied knowledge, by explicitly foregrounding knowledge, reflection, connection, synthesis and research, and placing renewed emphasis to what is to be learned, and how.

While policy reform measures were accompanied by a range of teacher training initiatives and programmes - specifically geared at curriculum content knowledge - very little, if any attention was (and is) given to who teachers are, and what they bring into the classroom. As Britzman $(1992,23)$ observes, it is problematic when a teacher's identity is taken for granted, when it is approached as "embedded in the normative discourse of teacher education where the glorification of first-hand experience non-problematically scripts teacher identity synonymous with the teacher's role and function". Teachers, we know, play fundamental roles in shaping not only the teaching and learning encounters, but in influencing learners' desire and interest to attend school, in the first place. Educational reform in South Africa is not remiss of the importance of the role of teachers, and the need for training and innovation, but educational reform policies persist in constructing and understanding "teachers" as a generic collectivity. Every education policy document, states Jansen (2001, 242), whether explicitly or implicitly, refers to "preferred and cherished images" about "the teacher" - creating (mis)impressions of uncritical homogeneity in terms of identity and professionalism. Firstly, an idealised version of "the teacher" simply does not exist; secondly, numerous teachers in South African schools are in the profession, not out of choice, but because it was their only option of pursuing a postschooling qualification; thirdly, a number of teachers are either unequipped, or unwilling to embark on the types of teaching practices, as necessitated and instructed through educational reform policies - in other words, they are not prepared to advance democratic citizenship education, in support of South Africa's educational reform.

Currently, as Van Broekhuizen $(2016,1)$ notes, South Africa is faced both with an absolute shortage of teachers and a relative shortage of adequately qualified and competent teachers, 
particularly in key areas like mathematics and the physical sciences - both of which serve as a constraint to improving educational outcomes in South Africa. There are numerous reasons for the pervasiveness of the country's teacher shortages, why such shortages persist, and the most appropriate policy interventions through which those shortages may be redressed - as Van Broekhuizen (2016) sets out to do. We share his interest and concern, but for the purposes of this article, we are especially interested in who the teachers are, and what the implications of this who might be for teacher education.

\section{STUDENT ENROLMENT STATISTICS}

Generally, in South Africa, and as is the case at the institution where we are based, students intending to attain a teaching qualification opt for one of two teacher education programmes: a one-year post-degree qualification - the Postgraduate Certificate in Education (PGCE) - or a four-year integrated teacher qualification - the BEd. Following the Minimum Requirements for Teacher Education (DHET 2015, 15), the primary purpose of the PGCE, as is the case with all Initial Teacher Education (ITE) qualifications in South Africa, is to certify that the student has specialised as a beginning teacher in a specific phase and/or subject. In addition to the particular specialisation of the student or pre-service teacher, is a practical learning component, which must be appropriately structured and fully integrated into overall learning programmes, and include structured supervision, mentoring and assessment.

Despite the obvious problems associated with the continuing use of racial categories - the same ones of those employed during apartheid - public entities, including educational institutions, request and use these categories as a means of tracking the pace of transformation. As teachers and academics, we find ourselves at an ethical crossroads as we write this article. On the one hand, we are in full agreement that race is an entirely social construction, without any biological basis or implication, and as such plays no role in the who an individual is or becomes. We share commonly held concerns that the continuing use of these categories and language not only perpetuates apartheid-shaped exclusion, marginalisation and fractured-ness, but have been imposed upon new generations of a democratic society. On the other hand, we recognise that the ideological demise of apartheid is not to be conflated or confused with the end of racism, and its vitriol. Moreover, the types of desegregation envisaged through various school-based and higher education acts and policies have not been actualised in practices. The higher education system, for example, was completely overhauled as an integrated, "single, national co-ordinated system that would ensure diversity in its organisational form and the institutional landscape, mix of institutional missions and programmes commensurate with national and regional needs in social, cultural and economic development" (DoE 1997, 2.3). 
Policies, such as the White Paper 3: A Programme for the Transformation of Higher Education (DoE 1997); the Higher Education Amendment Act (DoE 1998), and the National Plan for Higher Education (DoE 2001) are intent upon differentiating post-apartheid higher education from its widely disparate past, while simultaneously attempting to satisfy utilitarian demands in the service of the government and the public.

Consequently, the National Plan for Higher Education (DoE 2001) proposes the achievement of 16 outcomes which range from increasing student access, particularly of black communities into the university sector, to enhancing their (students') cognitive abilities with respect to technical and professional competences that would not only ensure greater competitiveness in an ever-evolving labour market economy but also increased participation as democratic citizens in service of the "public good". In South Africa, the participation rate in higher education increased from 15 per cent in 2000 to 18 per cent in 2010, and it was expected that the 20 per cent target would have been met by 2015/2016 (CHE 2013). Although significantly higher than the average gross enrolment ratio for sub-Saharan Africa, which is under 10 per cent, the South African higher education participation rate is well below the average for Latin America (34\%) and Central Asia (31\%). The CHE (2013, 41) report concludes: "Despite the growth, it is clear that the low participation rate continues to act as a brake on social and economic development and is a key factor in explaining the shortage of high-level skills. This is compounded by poor completion rates."

Increasing participation rates of students is seen as critical to the democratisation of access by making higher education accessible to diverse sections of the population, and benefitting groups which, historically, have been excluded from the elite systems of higher education (Akalu 2016). Underscoring this argument is an idea that an increase in student enrolment constitutes broadening and diversifying higher education spaces. Moreover, an increase in diversity of students signals a greater chance of different voices and perspectives, thereby ensuring that higher education becomes more representative and reflective of its society.

Following the above, the rest of this article looks at the statistics of student enrolments for the BEd (Foundation and Intermediate phase), and PGCE programmes over a five-year period.

Table 1: BEd Programme (Foundation and Intermediate phase): Student enrolment per race and gender (2016-2020)

\begin{tabular}{|l|c|c|c|c|c|c|c|c|c|c|}
\hline Category & $\mathbf{2 0 1 6}$ & $\mathbf{\%}$ & $\mathbf{2 0 1 7}$ & $\mathbf{\%}$ & $\mathbf{2 0 1 8}$ & $\mathbf{\%}$ & $\mathbf{2 0 1 9}$ & $\mathbf{\%}$ & $\mathbf{2 0 2 0}$ & $\%$ \\
\hline White & 658 & 66,53 & 631 & 64,98 & 638 & 64,19 & 590 & 61,78 & 576 & 60,57 \\
\hline Female & 610 & 61,68 & 586 & 60,35 & 585 & 58,85 & 547 & 57,28 & 534 & 56,15 \\
\hline Male & 48 & 4,85 & 45 & 4,63 & 53 & 5,33 & 43 & 4,50 & 42 & 4,42 \\
\hline
\end{tabular}




\begin{tabular}{|l|c|c|c|c|c|c|c|c|c|c|}
\hline Category & $\mathbf{2 0 1 6}$ & $\mathbf{\%}$ & $\mathbf{2 0 1 7}$ & $\mathbf{\%}$ & $\mathbf{2 0 1 8}$ & $\mathbf{\%}$ & $\mathbf{2 0 1 9}$ & $\mathbf{\%}$ & $\mathbf{2 0 2 0}$ & $\mathbf{\%}$ \\
\hline Coloured & 296 & 29,93 & 303 & 31,20 & 312 & 31,39 & 319 & 33,40 & 314 & 33,02 \\
\hline Female & 219 & 22,14 & 223 & 22,97 & 228 & 22,94 & 234 & 24,50 & 234 & 24,61 \\
\hline Male & 77 & 7,79 & 80 & 8,24 & 84 & 8,45 & 85 & 8,90 & 80 & 8,41 \\
\hline Black African & 31 & 3,13 & 30 & 3,09 & 32 & 3,22 & 29 & 3,0 & 43 & 4,52 \\
\hline Female & 18 & 1,82 & 14 & 1,44 & 15 & 1,51 & 13 & 1,36 & 28 & 2,94 \\
\hline Male & 13 & 1,31 & 16 & 1,65 & 17 & 1,71 & 16 & 1,68 & 15 & 1,58 \\
\hline Indian & 4 & 0,40 & 7 & 0,72 & 7 & 0,70 & 9 & 0,94 & 4 & 0,42 \\
\hline Female & 3 & 0,30 & 5 & 0,51 & 5 & 0,50 & 7 & 0,73 & 1 & 0,11 \\
\hline Male & 1 & 0,10 & 2 & 0,21 & 2 & 0,20 & 2 & 0,21 & 3 & 0,32 \\
\hline Asian & 0 & 0,00 & 0 & 0,00 & 1 & 0,10 & 1 & 0,10 & 3 & 0,32 \\
\hline Female & 0 & 0,00 & 0 & 0,00 & 1 & 0,10 & 1 & 0,10 & 3 & 0,32 \\
\hline Male & 0 & 0,00 & 0 & 0,00 & 0 & 0,00 & 0 & 0,00 & 0 & 0,00 \\
\hline Withheld & 0 & 0,00 & 0 & 0,00 & 4 & 0,40 & 7 & 0,73 & 11 & 1,16 \\
\hline Female & 0 & 0,00 & 0 & 0,00 & 3 & 0,30 & 6 & 0,63 & 9 & 0,95 \\
\hline Male & 0 & 0,00 & 0 & 0,00 & 1 & 0,10 & 1 & 0,10 & 2 & 0,21 \\
\hline Total & 989 & & 971 & & 994 & & 955 & & 951 & \\
\hline
\end{tabular}

Table 2: PGCE Programme: Student enrolment per race and gender (2016-2020)

\begin{tabular}{|c|c|c|c|c|c|c|c|c|c|c|}
\hline Category & 2016 & $\%$ & 2017 & $\%$ & $\begin{array}{l}\text { Per } \\
\text { race } \\
2018\end{array}$ & $\%$ & 2019 & $\%$ & 2020 & $\%$ \\
\hline White & 122 & 67,78 & 115 & 60,85 & 141 & 59,00 & 112 & 48,91 & 128 & 45,39 \\
\hline Female & 95 & 52,78 & 90 & 47,62 & 120 & 50,21 & 90 & 39,30 & 101 & 35,82 \\
\hline Male & 27 & 15,00 & 25 & 13,23 & 21 & 8,79 & 22 & 9,61 & 27 & 9,57 \\
\hline Non-binary & & 0,00 & & 0,00 & 0 & 0,00 & 0 & 0,00 & 1 & 0,35 \\
\hline Coloured & 44 & 24,44 & 67 & 35,45 & 76 & 31,80 & 80 & 34,93 & 100 & 35,46 \\
\hline Female & 30 & 16,67 & 51 & 26,98 & 58 & 24,27 & 57 & 24,89 & 71 & 25,18 \\
\hline Male & 14 & 7,78 & 16 & 8,47 & 18 & 7,53 & 23 & 10,04 & 29 & 10,28 \\
\hline Non-binary & & 0,00 & & 0,00 & 0 & 0,00 & 0 & 0,00 & 0 & 0,00 \\
\hline Black African & 12 & 6,67 & 4 & 2,12 & 19 & 7,95 & 32 & 13,97 & 48 & 17,02 \\
\hline Female & 9 & 5,00 & 1 & 0,53 & 12 & 5,02 & 20 & 8,73 & 28 & 9,93 \\
\hline Male & 3 & 1,67 & 3 & 1,59 & 7 & 2,93 & 12 & 5,24 & 20 & 7,09 \\
\hline Non-binary & & 0,00 & & 0,00 & 0 & 0,00 & 0 & 0,00 & 0 & 0,00 \\
\hline Indian & 2 & 1,11 & 3 & 1,59 & 2 & 0,84 & 3 & 1,31 & 1 & 0,35 \\
\hline
\end{tabular}




\begin{tabular}{|l|r|r|r|r|r|r|r|r|r|r|}
\hline \multicolumn{1}{|c|}{ Category } & $\mathbf{2 0 1 6}$ & $\boldsymbol{\%}$ & $\mathbf{2 0 1 7}$ & $\boldsymbol{\%}$ & $\begin{array}{r}\text { Per } \\
\text { race } \\
\mathbf{2 0 1 8}\end{array}$ & \multicolumn{1}{c|}{$\boldsymbol{\%}$} & $\mathbf{2 0 1 9}$ & $\mathbf{\%}$ & $\mathbf{2 0 2 0}$ & $\%$ \\
\hline Female & 2 & 1,11 & 2 & 1,06 & 2 & 0,84 & 3 & 1,31 & 1 & 0,35 \\
\hline Male & & 0,00 & 1 & 0,53 & 0 & 0,00 & 0 & 0,00 & 0 & 0,00 \\
\hline Non-binary & & 0,00 & & 0,00 & 0 & 0,00 & 0 & 0,00 & 0 & 0,00 \\
\hline Withheld & 0 & 0,00 & 0 & 0,00 & 1 & 0,42 & 2 & 0,87 & 5 & 1,77 \\
\hline Female & 0 & 0,00 & 0 & 0,00 & 1 & 0,42 & 2 & 0,87 & 3 & 1,06 \\
\hline Male & 0 & 0,00 & 0 & 0,00 & 0 & 0,00 & 0 & 0,00 & 2 & 0,71 \\
\hline Non-binary & 0 & 0,00 & 0 & 0,00 & 0 & 0,00 & 0 & 0,00 & 0 & 0,00 \\
\hline Total & $\mathbf{1 8 0}$ & & $\mathbf{1 8 9}$ & & $\mathbf{2 3 9}$ & & $\mathbf{2 2 9}$ & & $\mathbf{2 8 2}$ & \\
\hline
\end{tabular}

It is important to note that, historically, the university where we are based was for the exclusive education of "white" students. It is, therefore. not unexpected that "white" students continue to constitute the majority of students in both the BEd and PGCE programmes. Statistics for the BEd students reflect five categories of students in terms of race and ethnicity - namely, "white", "coloured", "black African", "Indian", and "Asian"; data from the PGCE lists do not reflect an "Asian" category. The vast disparities between "white" and "black" students, in particular, provide as much commentary on the low number of "black" students, aspiring to enter the teaching profession, as it does on the overall comparative number of "black" students at this particular university. In this regard, it is worth mentioning that despite the comparative low numbers of "black" and "coloured" students, the Faculty of Education is considered as one of the "most transformed" faculties in terms of both student and academic demographics.

In both the BEd and PGCE programmes, one notes a significant and steady increase in the number of "coloured" students, particularly in the PGCE programme, which has seen the number increase from $44(24.4 \%)$ in 2016, to 100 (35.5\%) in 2020. While a similar increase is evident in the number of "Black African" PGCE students - from 6.07 per cent in 2016, to 17.02 per cent in 2020, the increase in the number of BEd "Black African" students has been minimal - with a mere 1.39 per cent increase over a five-year period. By contrast, the number of "white" students in the BEd programme has dropped from 66.53 per cent (in 2016) to 60.57 per cent (in 2020). A similar, and more significant downward trend is visible among the PGCE group from 67.78 per cent (in 2016) to 45.39 per cent (in 2020). In turn, the number of "Indian" students have fluctuated - with the highest percentage $(0.94 \%)$ in the BEd programme being recorded in 2019, and only one "Indian" PGCE student in 2020. An overall glance reveals a slight decrease in the total number of total BEd students (from 989 to 951). By contrast, the PGCE statistics show a steady increase from 180 (in 2016) to 282 students (in 2020). 
In terms of gender identification, the PGCE data set reveals the inclusion of a "non-binary" category seemingly first introduced in 2018. Among all the racial categories, and across both the BEd and PGCE programmes, females outnumber male students. In the case of "white" students on the BEd programme, the ratio of females to males have consistently been 12:1. While the ratio is less pronounced among male and female students in the categories of "coloured", and "black African", these are significant nevertheless. In 2020, 24.61 per cent of "coloured" students identified as female, and 8.41 per cent as males; followed by 2.94 per cent "black African" females, and 1.58 per cent males.

The disparities between the number of males in the BEd and PGCE programme warrant careful attention. The PGCE programme is geared at teachers, who are planning to teach at high school level - that is, grades 8-12. The BEd programme, which focuses on primary school teaching, has two streams: BEd Foundation Phase (grades 1-3); and BEd Intermediate Phase (grades 4-7).

Table 3: BEd and PGCE: Gender breakdown

\begin{tabular}{|c|c|c|c|c|c|}
\hline \multirow{2}{*}{ Year } & \multicolumn{3}{|c|}{ BEd } & \multicolumn{3}{c|}{ PGCE } \\
\cline { 2 - 6 } & Females & Males & Females & Males & Non-binary \\
\hline $\mathbf{2 0 1 6}$ & 859 & 139 & 136 & 44 & 0 \\
\hline $\mathbf{2 0 1 7}$ & 828 & 143 & 144 & 45 & 0 \\
\hline $\mathbf{2 0 1 8}$ & 837 & 157 & 193 & 46 & 0 \\
\hline $\mathbf{2 0 1 9}$ & 853 & 147 & 195 & 57 & 0 \\
\hline $\mathbf{2 0 2 0}$ & 809 & 142 & 203 & 78 & 1 \\
\hline Total & $\mathbf{4 1 8 6}$ & $\mathbf{7 2 8}$ & $\mathbf{8 7 1}$ & $\mathbf{2 7 0}$ & $\mathbf{1}$ \\
\hline
\end{tabular}

Apparent from the data in Table 3, is that over a five-year period, of the number of students entering the BEd programme, $4186(85.1 \%)$ were female, while $728(14 \%)$ were male. Of the students entering the PGCE, 871 (76.3\%) were female, and $270(23.6 \%)$ were male, and one non-binary. In the BEd programme, the number of male students has fluctuated across the five years - with a decline over the last three years. By contrast, the number of PGCE male students has increased slowly over the same period, with a significant increase from 57 (in 2019) to 78 (in 2020). Of interest and concern is the comparatively low number of males entering the teaching profession, especially at the primary level - a trend, which, of course, is not unique to South Africa.

In summary, in terms of racial categories, in both programmes, "white" students continue 
to constitute the majority. This majority, however, is declining among the PGCE group - where there is seemingly a consistent increase in the number of "coloured" and "black African" students. Similar increases are not evident in the "Indian" category in either the BEd or PGCE programmes. In terms of gender, female students outnumber male students by 85 per cent in the BEd programme, and 76.3 per cent in the PGCE programme. These disparities, in terms of race and gender, have particular implications for teacher education, as will be discussed next in this article.

\section{IMPLICATIONS FOR TEACHER EDUCATION}

There are numerous complexities associated with, and offered in explanation of the dearth of minority-group teachers ("coloured"; "black"; "Indian") in schools. One is a somewhat simplified argument of an inadequate labour supply pipeline. Although largely untested, state Ingersoll, May and Collins $(2019,4)$, the assumption has been that an inadequate initial supply, coupled with barriers to entry, are the main reasons that insufficient numbers of minority-group teachers are employed. Consequently, continue Ingersoll et al. (2019), attention has tended to focus on identifying obstacles to recruiting minority candidates into teaching and, in turn, developing strategies to overcome these obstacles. In contrast, little attention has been paid to where minority teachers tend to be employed, what happens to minority teachers once they are employed, or to the role of the employing organizations in teacher staffing problems (Ingersoll et al. 2019).

Citing the American context, Ingersoll et al. (2019, 5), explain that the prevailing policy response to minority-group teacher staffing problems has been to attempt to increase the supply pipeline of minority teachers. Over the past several decades, for example, organisations such as the Education Commission of the States, the American Association of Colleges of Teacher Education, and the National Collaborative on Diversity in the Teaching Force have advocated for and implemented a wide range of initiatives designed to recruit minority candidates into teaching (Ingersoll et al. 2019). Many of these initiatives, report Ingersoll et al. $(2019,5)$, have been designed to recruit minority-group teachers to teach in schools serving predominantly minority student populations, often in low-income, urban school districts. In addition, some of these initiatives have been designed to recruit male minority teachers, in particular - often considered the group in shortest supply (Ingersoll et al. 2019). Similar initiatives have been launched in South Africa. One example is the Funza Lushaka Bursary programme, offered by the national Department of Basic Education (DBE). It is described as a service-linked, "multiyear programme that was launched in 2007 to promote teaching in public schools as the career of choice for able and committed South Africans. Full-cost bursaries are available to enable 
eligible students to complete a full teaching qualification in an area of national priority" (DBE 2009). Recipients of the bursary are required to teach in a public school, registered in a provincial education department, immediately after qualifying, and for the same number of years that they have received a bursary (DBE 2009). Areas of national priority include the following:

- Grades R-3 (Foundation Phase): Foundation Phase specialisation.

- Grades 4-6 (Intermediate Phase): African languages; English; Mathematics; Natural Sciences; and Technology

- Grades 7-9 (Senior Phase): African languages; English; Mathematics; Natural Sciences; and Technology

- Grade 10-12 (FET Phase): Accounting; African languages; Economics; English; Geography; Mathematics; Mathematical Literacy; Agricultural Sciences; Life Sciences; Physical Sciences; Agricultural Technology; Civil Technology; Electrical Technology; Mechanical Technology; Information Technology; Computer Applications Technology; as well as Engineering Graphics and Design (DBE 2009, 18).

In addition to encouraging students in the direction of teaching subjects, considered as a national priority, the Funza Lushaka Bursary Programme, is geared at filling posts particularly in poor and rural areas. The Funza Lushaka Bursary Programme, according to Van Broekhuizen (2016, 24), has expanded considerably over a relatively short period of time, with the number of bursaries being awarded each year rising by an estimated 22.4 per cent, on average, per annum from 3670 in 2007 to just over 14500 in 2013. However, although one of the programme's aims is to fund at least 25 per cent of ITE students at public higher education institutions, the closest it has come to achieving this objective was in 2009 and 2010 when the total number of Funza Lushaka Bursary Programme recipients respectively amounted to 21.8 per cent and 19.2 per cent of the numbers of individuals enrolled in ITE programmes. This is not the only concern. According to Van Broekhuizen $(2016,25)$ it is often implied that the Funza Lushaka Bursary Programme has played a major role in relation to increasing student enrolments in ITE. This, however, might not necessarily be the case. The fact that the introduction and subsequent expansion of Funza Lushaka coincided with an increase in ITE programme enrolments between 2006 and 2013, contends Van Broekhuizen (2016, 25) is not, in itself, evidence that the bursary programme has had a causal impact on the number of individuals deciding to enrol in such programmes over the period.

In the absence of research into the correlation between the introduction of a bursary 
programme and research, as well as to whether the bursary recipients indeed teach at rural schools, where the needs are greatest, it is hard to offer definitive insights. What we do know, however, is that South Africa's teacher shortage has persisted. On the one hand, we agree with Van Broekhuizen $(2016,1)$, that we need to understand the underlying dimensions and pervasiveness of the country's teacher shortages, the reasons why such shortages persist, and the most appropriate policy interventions through which those shortages may be redressed. On the other hand, we recognise, as teacher educators, that part of addressing the shortage of teachers in South Africa, and addressing the criticality of adequate representation in terms of race and gender, is by paying renewed attention to what happens on teacher education programmes.

Our faculty offers a rich base for reflection and learning. As we have previously indicated, the university where we are based is historically white and privileged. Despite pronouncements on an urgency for transformation, there remains two concerns. One pertains to the fact that the university transformation pace in terms of student access is not in line with most other historically advantaged institutions. The Faculty of Education - with its mediocre record of student diversity - is worryingly described and applauded as one of the most "transformed" faculties at the university. The second concern relates to conceptualisations and practices of transformation, which are by no means unique to our institution. Massification of student enrolment continues to be reduced to an understanding of increasing student numbers. In other words, historically advantaged institutions continue to be preoccupied with increasing student enrolment - as a marker of external transformation - when the real problem resides in what happens to students after that they have been granted access. How do students from historically diverse, disadvantaged and marginalised communities navigate the spaces of historically advantaged institutions? We cannot assume that external inclusion, as Young (2000) points out, translates into internal inclusion? How do these students, therefore, find a sense of belonging so that they are not only alienated from the institution, but from the very professions they have opted to pursue?

Following the above, there are two areas in teacher education programmes, which we believe, can play meaningful roles in assisting students from minority groups to find points of resonance in their educational spaces and in the teaching profession. The first centres on the curriculum or content of teacher education programmes. Generally speaking - across university-based programmes - although there have been significant progress in transformation in some aspects of higher education (DoE 2008, 89), the curriculum has remained largely intact. By government's own admission, transformation efforts have not "translated into any significant shifts in the structure and content of the curriculum" (DoE 2008, 90). In turn, the 
curriculum "is inextricably intertwined with the institutional culture and, given that the latter remains white and Eurocentric at the historically white institutions, the institutional environment is not conducive to curriculum reform" (DoE 2008, 91). Academic performance is at the core of access, retention and success. It is in the classroom where students experience the highest sense of displacement and alienation - because they are neither "seen" nor "heard", and because they are unable to navigate the expectations of the classroom.

Although the dominant discourses of knowledge, communication and practice in higher education can be seen to vary significantly geographically, politically, socially and economically, as well as between institutions, between faculties, and between disciplines, it is nevertheless, defined by particular discourses, which constitute academic and institutional cultures (Read, Archer and Leathwood 2003, 261). In this regard, in order for students to feel "seen" and "heard", it becomes necessary for the (our) Faculty to ensure that the diverse identities, lives of students, as well as their knowledge forms are reflected in the content of their teacher education programme. Teaching, we know is fundamentally a relational practice. Irrespective of its geographical location, teaching is always influenced and impacted upon by specific social-cultural contexts, which are constantly changing and are fraught with moral ambiguity (Orchard, Heilbronn and Winstanley 2016). Pre-service teachers do not yet have the necessary knowledge, skills, and aptitudes to navigate these contingencies, and our Faculty is certainly not the only teacher education space in Africa, or elsewhere, where the priority of teaching as a relational practice, is being neglected.

Students from minority-groups, states Sleeter $(2001,94)$, tend to bring richer experiences and perspectives to multicultural teaching than do most "white students", who dominate numerically. Although a large proportion of "white" pre-service students anticipate working with children of another cultural background, as a whole, however, asserts Sleeter (2001, 94), they ("white" pre-service students) bring very little cross-cultural background, knowledge, and experience. The point being made here is that students, like teachers, are a resource. Who they are, what they bring in terms of perspectives and perceptions, can be used towards the enhancement of curriculum content. The relationality of teaching implies that teaching is not a one-dimensional process whereby teachers speak or instruct, and students listen and receive knowledge. The relationality of teaching demands contextual cognisance, as presented and (re)presented by students. The curriculum content cannot be dismissive or neglectful of the importance of tying educational content and pedagogy to issues of democratic citizenship education, and social justice education. In South Africa, curriculum renewal and transformation are couched in calls for decolonisation. By implication, curriculum transformation is conceived as reflective of societal transformation. Decolonisation, according to Smith (1999) involves 
deconstruction and reconstruction; self-determination and social justice; ethics, language, internationalisation of indigenous experiences, history and critique. In sum, curriculum transformation should emanate from, and embody the lived experiences of indigenous people, who, in this case, have also been subjected to colonialism and apartheid.

Linked to the concern about the curriculum, is the second area, which concerns the identity of the teacher-educator. According to Sleeter $(2001,96)$, pre-service teacher education programmes take two rather different - but not mutually exclusive - lines of action to address the cultural gap between teachers and children in the school. On the one hand, the programmes attempt to attract more teachers who are from culturally diverse communities. And, on the other hand, they try to develop the attitudes and multicultural knowledge base of predominantly "white" cohorts of pre-service students. Our faculty, for example, embarks on a series of annual roadshows in order to increase student enrolment from minority-groups, but attempts to develop the attitudes and multicultural knowledge of "white" students are not necessarily smoothflowing. This is not necessarily because of the students, but because of the embeddedness of certain norms and practices, which have remained unchanged in the faculty, despite existing in a context of immense political, social and educational reform.

Teachers, as we have previously argued, matter (Waghid and Davids 2020). They matter, because they bring much more than content knowledge and ensuring students' academic success. Teachers matter insofar as they influence, motivate, and inspire, and challenge students to think, and step outside of who they are and into the experiences of others (Waghid and Davids 2020). Our Faculty is not alone in experiencing great challenges in ensuring that students feel included and recognised. Much of this struggle and disconnection stems from either an incapacity or unwillingness to connect with students, who are different in terms of background and worldview. To a number of academics in our faculty, dealing with diverse students is unfamiliar territory; often, very little, if any, attempts are made to get to know all students as they are. As a result, students from minority-groups report feeling a deep sense of alienation, not only from their institutional space, but from the profession for which they are preparing. It is exceptionally problematic when the faculty's teacher education programme - which has a strong emphasis on social justice, inclusion, multiculturalism, and democratic citizenship education - is not evident in the pedagogies and attitudes of academics, or teacher-educators. In other words, there is a schism between what is being propagated in terms of content, and what is made evident through the practices of academics.

It is our contention that much depends on the teacher; this responsibility is intensified by virtue of the roles of teachers, who teach and prepare teachers. Many of our students have experienced schooling environments and systems of homogeneity and conformity - not 
necessarily because there was no learner diversity, but because the management of diversity is often interpreted and implemented as a minimisation thereof, as manifested through assimilation. As a result, it becomes the responsibility of the faculty and its academics to invite students to analyse and to question what they know, how they have come to know what they know, and why they believe it to be their truth. A good teacher disrupts taken-for-granted views, and provokes students into imagining how things might be otherwise.

\section{CONCLUDING REMARKS}

We commenced this article by providing some background insights into the transition of teacher education programmes from an apartheid to a democratic South Africa. We highlighted that while policy reform measures were accompanied by a range of teacher training initiatives and programmes - specifically geared at curriculum content knowledge - very little, if any attention was (and is) given to who teachers are, and what they bring into the classroom. In this sense, scant attention is given to teacher identity, and how teachers engage with learners or students form diverse backgrounds - a neglect, we argue, has particular implications for teacher education. We continued by paying specific attention the enrolment statistics of two teacher education programmes - PGCE and BEd - at the university where we are based. We showed that after 26 years since our institution "opened" its doors to students from all racial and ethnic groups, the student demographics are not representative of South African society. We found that "white" students continue to constitute the majority of students in both the BEd and PGCE programmes, with a significant and steady increase in the number of "coloured" students, particularly in the PGCE programme. While a similar increase is evident in the number of "Black African" PGCE students, the increase in the number of BEd "Black African" students has been minimal. By contrast, the number of "white" students in the BEd programme has dropped. Moreover, among all the racial categories, and across both the BEd and PGCE programmes, females outnumber male students. In the case of "white" students on the BEd programme, the ratio of females to males have consistently been 12:1. While the ratio is less pronounced among male and female students in the categories of "coloured", "black African", these are significant nevertheless.

We concluded the article by considering the implications for teacher education programmes - in addressing representation of minority groups. We argued that teaching, we know is fundamentally a relational practice, irrespective of its geographical location. This implies that teaching is not a one-dimensional process whereby teachers speak or instruct, and students listen and receive knowledge. The relationality of teaching demands contextual cognisance, as presented and (re)presented by students. The curriculum content cannot be 
dismissive or neglectful of the importance of tying educational content and pedagogy to issues of democratic citizenship education, and social justice education. In turn, similar attention should be afforded to the identity of the teacher-educator. Teachers, we maintained, matter, because they bring much more than content knowledge and ensuring students' academic success; good teachers disrupt taken-for-granted views, and provokes students into imagining how things might be otherwise.

\section{REFERENCES}

Akalu, G. A. 2016. Higher education "massification" and challenges to the professoriate: Do academics' conceptions of quality matter? Quality in Higher Education 22(3): 260-276.

Britzman, D. P. 1992. The terrible problem of knowing thyself: Toward a poststructural account of teacher identity. Journal of Curriculum Theorizing 9(3): 23-46.

CHE see Council on Higher Education.

Chisholm, L. 2009. An overview of research, policy and practice in teacher supply and demand 19942008. Cape Town: HSRC Press.

Council on Higher Education. 2013. A proposal for undergraduate curriculum reform in South Africa: The case for a flexible curriculum structure. Pretoria: Council on Higher Education.

DBE see Department of Basic Education.

Department of Basic Education. 2009. Information guide on initial teacher education. Pretoria: Government Printers.

Department of Education. 1997. Education White Paper No. 3: A programme on the transformation of higher education transformation. Pretoria: Government Printers.

Department of Education. 1998. Higher Education Amendment Act. Pretoria: Government Printers.

Department of Education. 2000. Norms and standards for educators. Pretoria: Government Printers.

Department of Education. 2001. National plan for higher education. Pretoria: Government Printers.

Department of Education. 2008. Report of the ministerial committee on transformation and social cohesion and the elimination of discrimination in public higher education institutions, (final report). Pretoria: Government Printers.

Department of Higher Education and Training 2015. Minimum Requirements for Teacher Education Qualifications. Pretoria: Government Printers.

DHET see Department of Higher Education and Training.

DoE see Department of Education.

Ingersoll, R., H. May and G. Collins. 2019. Recruitment, employment, retention and the minority teacher shortage. Education Policy Analysis Archives 27(37): 1-37.

Jansen, J. D. 2001. Image-ining teachers: Policy images and teacher identity in South African classrooms. South African Journal of Education 21(4): 242-246.

Orchard, J., R. Heilbronn and C. Winstanley. 2016. Philosophy for teachers (P4T): Developing new teachers' applied ethical-decision making. Ethics and Education 11(1): 42-54.

Read, B., L. Archer and C. Leathwood. 2003. Challenging cultures? Student conceptions of "belonging" and "isolation" at a post-1992 university. Studies in Higher Education 28(3): 261-277.

Sleeter, C. E. 2001. Preparing teachers for culturally diverse schools research and the overwhelming presence of whiteness. Journal of Teacher Education 52(2): 94-106.

Smith, L. 1999. Decolonising methodologies: Research and indigenous peoples. London: Zed Books. 
Van Broekhuizen, H. 2016. Teacher supply in South Africa: A focus on initial teacher education graduate production. Stellenbosch Economic Working Papers: WP07/15.

Waghid, Y. and N. Davids, N. 2020. Teachers Matter: Educational Philosophy and Authentic Learning. Lanham, MD (US): Rowman \& Littlefield - Lexington Series

Young, I. M. 2000. Inclusion and democracy. Oxford: Oxford University Press. 